\title{
Comparison of diagnostic value of visual inspection with Lugol's iodine to conventional Paps smear in detection of colposcopic biopsy proved CIN: a tertiary care experience
}

\author{
Manisha Bajaj $^{1}$, Shamshad Ahmad ${ }^{1 *}$, Shubha S. Trivedi ${ }^{2}$
}

\begin{abstract}
${ }^{1}$ Department of Obstetrics and Gynecology, ESI-PGIMSR and ESIC Medical College, Joka, Kolkata, West Bengal, India

${ }^{2}$ Department of Obstetrics and Gynecology, SGT Medical College, Hospital and Research Institute, Gurugram, Haryana, India
\end{abstract}

Received: 26 September 2017

Accepted: 30 October 2017

\section{*Correspondence:}

Dr. Shamshad Ahmad,

E-mail: ahmad.esi.joka@gmail.com

Copyright: (c) the author(s), publisher and licensee Medip Academy. This is an open-access article distributed under the terms of the Creative Commons Attribution Non-Commercial License, which permits unrestricted non-commercial use, distribution, and reproduction in any medium, provided the original work is properly cited.

\begin{abstract}
Background: An organized cytological screening (Pap smear) is the mainstay for cervical cancer prevention and control programme. Financial and logistic burden of operating such a program is considerable. This has prompted the evaluation of alternative feasible techniques. It appeared from the earlier studies that visual inspection with lugol's iodine (VILI) could be a potential alternative to cervical cytology. VILI is a low cost, easy to apply and highly sensitive technique. It gives result immediately thus allows doctors to "see and treat" at first visit. Objective of present study was to evaluate the performance of visual inspection with lugol's iodine and its comparison with cytology in cervical cancer screening.

Methods: 400 non-pregnant reproductive age women were subjected to Paps and VILI in this prospective study done in a tertiary-care centre in Delhi. Reference standard used for all was colposcopy and colposcopic-directed biopsy (when required).

Results: Of 400 Pap smears done $11.75 \%$ were normal, $77.5 \%$ inflammatory, $5.5 \%$ had ASCUS, $0.25 \%$ ASC-H, $0.5 \%$ AGUS, $2 \%$ LSIL, $1.5 \%$ HSIL and invasive cancer in $0.5 \%$. With LSIL and above smears as significant, the sensitivity and specificity of Paps were $50 \%$ and $97.66 \%$ respectively. VILI was positive in $12.8 \%$ of cases. Sensitivity and specificity of VILI was $85.5 \%$ and $89.9 \%$ respectively. Overall accuracy of VILI in detecting preinvasive lesion was $89.7 \%$ while with pap smear it was $96 \%$.

Conclusions: Accuracy of VILI and Pap smear in detecting pre-invasive cervical lesion was comparable. At tertiarycare centers VILI can be used effectively to screen the patients with significant lesions. Patients can be directly subjected to further treatment at the earliest thus reducing loss to follow-up.
\end{abstract}

Keywords: Cervical cancer, Colposcopy, Screening, Sensitivity, Specificity

\section{INTRODUCTION}

Worldwide, India accounts for $25 \%$ of total burden of cervical cancer. ${ }^{1,2} 1$ in 53 Indian women have risk of getting cervical cancer in her life time. ${ }^{2}$ Cervical cancer has a long pre-invasive period. Screening programme during this period proved very effective for prevention of cervical cancer. ${ }^{3,4}$ Due to lack of proper infrastructure, many developing countries are still unable to provide efficient for cervical cancer.,

At present cervical cytology (Pap smear) is the backbone of cervical screening programme. Cytology based screening programme have been difficult to implement 
on a large scale basis in developing countries with little impact on the incidence of cervical cancer and mortality. ${ }^{7-9}$ This felt need prompted researcher to develop other alternative diagnostic screening tool. A tool which is affordable and suitable for large scale screening of cervical abnormalities. ${ }^{5,10}$

Visual inspection with lugol's iodine (VILI) is a modification of direct visual assessment of cervix. Few earlier studies reported VILI performed adequately in screening of cervical abnormalities and also comparative to Pap smear in low resource setting. ${ }^{11-13}$ But it was also associated with high rate of false-positive findings. ${ }^{14,15}$ There is limited evaluation of VILI as a screening test in hospital setting- a well-equipped health care set up so that they can replace or supplement Pap smear as primary screening tests even where resources are adequate. Thus, the present initiative was taken in view of exploring the feasibility, acceptability and accuracy of the alternative VILI that has come up as potential promising approach.

\section{METHODS}

This study was a hospital based non-randomized, analytical, descriptive, study. The women presenting to the gynecology OPD with various gynecological complaints were invited to participate in the study.

Patients having frank growth, postmenopausal bleeding per vaginum, using intravaginal medications, those with prior hysterectomy and those who took prior treatment for cancer cervix or cervical intra epithelial neoplasia were excluded. 400 sexually active patients who presented to the gynecological outpatient department with various gynecological complaints were evaluated and according to the exclusion and inclusion criteria were enrolled in the study.

The women who were eligible to participate and gave consent were thoroughly interviewed, histories were taken and general physical examinations were done. Pap smear was first taken. Then freshly prepared lugol's iodine was applied on the cervix and findings were carefully observed and documented according to criteria of International Agency for Research on Cancer (IARC) separately. Preparation of Lugol's iodine: 10gm of potassium iodide was dissolved in $100 \mathrm{ml}$ distill water. Next $5 \mathrm{gm}$ of iodine was added after the potassium iodide was fully dissolved. It was stirred well until all the iodine flakes have fully dissolved.

The preparation was stored in a dark colored sealed container to prevent evaporation of iodine and loss of staining activity. Following the screening tests, each patient was subjected to colposcopy in colposcopy room. If colposcopy was suspicious then only cervical biopsy was taken from the abnormal area/ areas.

In present study, no verification bias was there as all participants were subjected to diagnostic tests. The reference standard for defining final disease status was a combination of colposcopy and biopsy. ${ }^{16,17}$ Disease status was assessed based on histology if a biopsy was taken; if not, based on colposcopy. Reference standard negatives included women who were assessed as negative for suspicious lesions by colposcopy, as well as those who were assessed as positive by colposcopy, but negative by histology.

True disease was defined as histologically confirmed CIN 2 or greater lesion (IARC). Cytology result was reported according to the Bethesda system by pathologist and VILI documented according to the IARC criteria. The compiled results were statistically analyzed applying Chisquare, paired t-test and student's t-test. The sensitivity and specificity were calculated for each and comparison was done.

\section{RESULTS}

Table 1, showed that majority were of age group 26-45 years $(78.1 \%$ ) and $17.5 \%$ were less than 26 years of age. The mean age of the study group was $33.91 \pm 7.59$ years. which varied from 19-52 years.

\section{Table 1: Sociodemographic profile of patients} $(\mathrm{N}=400)$.

\begin{tabular}{|c|c|c|}
\hline Variables & Category & Number $(\%$ \\
\hline \multirow{4}{*}{ Age group } & $\leq 25$ years & $70(17.5)$ \\
\hline & 26-35years & $171(42.8)$ \\
\hline & $36-45$ years & $133(35.2)$ \\
\hline & $45-55$ years & $28(6.5)$ \\
\hline \multirow{3}{*}{ Occupation } & Housewife & $342(85.5)$ \\
\hline & Laborer or servant & $38(9.5)$ \\
\hline & $\begin{array}{l}\text { Service or business or } \\
\text { professional }\end{array}$ & $20(5.0)$ \\
\hline \multirow{2}{*}{$\begin{array}{l}\text { Socio- } \\
\text { economic status }\end{array}$} & Lower & $285(71.3)$ \\
\hline & Middle & $115(28.7)$ \\
\hline \multirow{4}{*}{$\begin{array}{l}\text { Educational } \\
\text { level }\end{array}$} & Illiterate & $176(44)$ \\
\hline & Elementary level (I-V) & $62(15.5)$ \\
\hline & Secondary level (VI-XII) & $129(32.3)$ \\
\hline & Graduate and higher & $33(8.3)$ \\
\hline \multirow{2}{*}{ Religion } & Hindu & $370(92.5)$ \\
\hline & Muslim and others & $30(7.5)$ \\
\hline
\end{tabular}

Postmenopausal women not included in the study as standard colposcopy is not reliable in them. The mean parity of women was $2.8 \pm 1.47$ ranging from $0-9$. Majority $(85.5 \%)$ of the patients was housewives and 92.5\% were Hindus. More than $50 \%$ were literate but only $8.3 \%$ were graduate or above. Illiterates also formed a significant part of the group.

The bulk of the group $(71.3 \%)$ was formed of patients from lower strata and there was no patient from upper class in the study. Lugol's iodine was applied on the cervix and observations noted. $87.1 \%$ of patients had negative test result and rest tested positive with lugol's iodine $(12.75 \%)$, Table 2 . 
Table 2: Distribution of observation after Lugol's iodine application.

\begin{tabular}{|c|c|c|}
\hline Observations & Interpretation & Number (n) \\
\hline $\begin{array}{l}\text { Normal cervix where } \\
\text { squamous epithelium } \\
\text { turned mahogany brown } \\
\text { or black and when SCJ } \\
\text { was visible the columnar } \\
\text { epithelium beyond it did } \\
\text { not change color }\end{array}$ & Negative & $\begin{array}{l}308 \\
(76.8 \%)\end{array}$ \\
\hline $\begin{array}{l}\text { Scattered or diffuse ill- } \\
\text { defined, colourless or } \\
\text { partially brown areas are } \\
\text { seen in the cervix; not } \\
\text { restricted to TZ }\end{array}$ & Negative & $28(7.1 \%)$ \\
\hline $\begin{array}{l}\text { Thin, yellow, non-iodine } \\
\text { uptake areas with angular } \\
\text { digitising margins, } \\
\text { resembling geographical } \\
\text { areas, distant from the SCJ }\end{array}$ & Negative & $13(3.3 \%)$ \\
\hline $\begin{array}{l}\text { Dense, thick, bright, } \\
\text { mustard-yellow, or } \\
\text { saffron yellow iodine } \\
\text { non- uptake areas } \\
\text { abutting the squamo- } \\
\text { columnar junction in the } \\
\text { transformation zone }\end{array}$ & Positive & $36(9.0 \%)$ \\
\hline $\begin{array}{l}\text { Circumferential yellow } \\
\text { non-iodine uptake area } \\
\text { around the external os }\end{array}$ & Positive & $15(3.8 \%)$ \\
\hline
\end{tabular}

Table 3, A detailed correlation of the Pap smear report with reference standard (colposcopy or biopsy) was done. Out of 400 Pap smears done 310 had inflammatory report of which only 32 had suspicious colposcopy which when subjected to biopsy- chronic cervicitis was reported in 27 and CIN 2 in 5 patients. Of the 47 normal pap reports only one had suspicious colposcopy which on biopsy revealed chronic cervicitis.

Among 22 ASCUS 6 had suspicious colposcopy but only 2 had CIN 2 reported. No significant lesion was found with AGUS or ASC-H on Paps. There were 8 LSIL reported in the study group of which only two were colposcopically found suspicious. Out of these two, one had CIN 2. Out of the 6 HSIL reported 5 were colpscopically abnormal which were then subjected to biopsy. The results were CIN 2 in two patients, CIN 3 in one and one had invasive cancer. Each case of squamous cell carcinoma and adenocarcinoma reported on Paps were confirmed on histological examination. On detailed correlation of biopsy results with VILI the following observation were made. The positivity rate of VILI is $12.75 \%$. Only 18 of the total 51 positive reports were not suspicious on colposcopy rest 33 underwent cervical biopsy wherein majority were chronic cervicitis (16). Two of them were unremarkable and one tubercular. Of rest 9 were reported to be CIN 2 and CIN 3 and three invasive cancers.

Table 3: Distribution of Pap smear and VILI findings in relation to biopsy $(\mathrm{N}=400)$.

\begin{tabular}{|c|c|c|c|c|c|c|c|c|c|}
\hline \multirow[b]{2}{*}{ Pap Smear } & \multicolumn{9}{|c|}{ Colposcopy/ Biopsy $(\mathrm{n}=\mathbf{5 1})$} \\
\hline & Normal & $\begin{array}{l}\text { Chronic } \\
\text { Cervicitis }\end{array}$ & Unremarkable & $\begin{array}{l}\text { CIN } \\
2\end{array}$ & $\begin{array}{l}\text { CIN } \\
3\end{array}$ & $\begin{array}{l}\text { Sq. cell } \\
\text { ca. }\end{array}$ & $\begin{array}{l}\text { Adeno- } \\
\text { carcinoma }\end{array}$ & $\begin{array}{l}\text { Granulomatous/ } \\
\text { TB }\end{array}$ & Total \\
\hline Normal & 46 & 1 & 3 & 0 & 0 & 0 & 0 & 0 & 47 \\
\hline Inflammation & 278 & 27 & 0 & 5 & 0 & 0 & 0 & 0 & 310 \\
\hline ASCUS & 16 & 4 & 0 & 2 & 0 & 0 & 0 & 0 & 22 \\
\hline $\mathrm{ASCH}$ & 1 & 0 & 0 & 0 & 0 & 0 & 0 & 0 & 1 \\
\hline AGUS & 0 & 2 & 0 & 0 & 0 & 0 & 0 & 0 & 2 \\
\hline LSIL & 6 & 1 & 0 & 1 & 0 & 0 & 0 & 0 & 8 \\
\hline HSIL & 1 & 1 & 0 & 2 & 1 & 1 & 0 & 0 & 6 \\
\hline SQ Cell Ca & 0 & 0 & 0 & 0 & 0 & 1 & 0 & 0 & 1 \\
\hline Adeno ca & 0 & 0 & 0 & 0 & 0 & 0 & 1 & 0 & 1 \\
\hline $\begin{array}{l}\text { Epitheloid } \\
\text { granuloma }\end{array}$ & 0 & 0 & 0 & 0 & 0 & 0 & 0 & 1 & 1 \\
\hline Total (\%) & 349 & 33 & & 10 & 1 & 2 & 1 & 1 & 400 \\
\hline \multicolumn{10}{|l|}{ VILI } \\
\hline Negative & 331 & 17 & 1 & 2 & 0 & 0 & 0 & 0 & 349 \\
\hline Positive & 18 & 16 & 2 & 8 & 1 & 2 & 1 & 1 & 51 \\
\hline Total (\%) & 349 & 33 & 3 & 10 & 1 & 2 & 1 & 1 & 400 \\
\hline
\end{tabular}

With LSIL and above smears were as positive, the sensitivity and specificity were $50 \%$ and $97.66 \%$ respectively while NPV and PPV were $98.1 \%$ and $43.75 \%$ respectively in the study.
The results confirm the fact that cytology is a test with low sensitivity but very high specificity. The sensitivity of VILI was $85.5 \%$ and specificity $89.9 \%$ in the study (Table 4). 
Table 4: Comparison of Pap smear and VILI in relation to reference standard (biopsy).

\begin{tabular}{|c|c|c|c|}
\hline & $\begin{array}{l}\text { Pap smear } \\
\text { ( } \geq \text { LSIL) }\end{array}$ & $\begin{array}{l}\text { Pap smear } \\
\text { ( } \geq \text { HSIL) }\end{array}$ & VILI+ \\
\hline $\begin{array}{l}\text { Sensitivity } \\
(95 \% \text { CI) }\end{array}$ & $\begin{array}{l}50.0 \% \\
(23.0,76.9)\end{array}$ & $\begin{array}{l}42.8 \% \\
(17.6,71.2)\end{array}$ & $\begin{array}{l}85.5 \% \\
(52.2,98.2)\end{array}$ \\
\hline $\begin{array}{l}\text { Specificity } \\
(95 \% \text { CI })\end{array}$ & $\begin{array}{l}97.6 \% \\
(95.6,98.9)\end{array}$ & $\begin{array}{l}99.4 \% \\
(98.1,99.4)\end{array}$ & $\begin{array}{l}89.9 \% \\
(86.4,92.2)\end{array}$ \\
\hline $\begin{array}{l}\text { PPV } \\
(95 \% \mathrm{CI})\end{array}$ & $\begin{array}{l}43.7 \% \\
(25.3,64.1)\end{array}$ & $\begin{array}{l}75 \% \\
(39.8,93.3)\end{array}$ & $\begin{array}{l}23.5 \% \\
(17.6,30.7)\end{array}$ \\
\hline $\begin{array}{l}\text { NPV } \\
(95 \% \mathrm{CI})\end{array}$ & $\begin{array}{l}98.1 \% \\
(96.9,98.9)\end{array}$ & $\begin{array}{l}97.9 \% \\
(96.8,98.6)\end{array}$ & $\begin{array}{l}99.4 \% \\
(97.6,99.8)\end{array}$ \\
\hline Accuracy & $96 \%$ & $97.5 \%$ & $89.7 \%$ \\
\hline
\end{tabular}

Table 5, depicted the correlation between various findings of Pap smear against VILI. Out of total 47 cases reported normal by Pap smear, only 2 were VILI+. Correlation was very poor for 310 inflammatory cases, as reported by Pap smear. Only 32 of them were VILI+. While for HSIL, squamous cell carcinoma, adenocarcinoma both test correlated perfectly.

Table 5: Correlation of cytology with visual screening tests.

\begin{tabular}{|llll|}
\hline PAPS & VILI +ve & VILI -ve & Total \\
\hline Normal & 2 & 45 & 47 \\
\hline Inflammation & 32 & 278 & 310 \\
\hline ASCUS & 6 & 16 & 22 \\
\hline ASCH & 0 & 1 & 1 \\
\hline AGUS & 1 & 1 & 2 \\
\hline LSIL & 1 & 7 & 8 \\
\hline HSIL & 6 & 0 & 6 \\
\hline Sqamous cell carcinoma & 1 & 0 & 1 \\
\hline Adeno-carcinoma & 1 & 0 & 1 \\
\hline Epitheloid granuloma & 1 & 0 & 1 \\
\hline Total & 51 & 349 & 400 \\
\hline
\end{tabular}

\section{DISCUSSION}

The present initiative was taken in view of the persistent high incidence and mortality of cervical cancer in India. Cytology became the mainstay of cervical cancer screening programs due to its significant success in western countries but failed to repeat its success in developing world due to financial, logistic, and technical problems.

Now visual screening tests are being evaluated and initial studies have found it to be feasible and acceptable. This study is an endeavor to address to these problems by assessing the performance of visual screening tests and exploring the possibility of using them as primary screening methods.

The mean age of the study group was $33.91 \pm 7.59$ years and majority was of age group $26-45$ years $(78.1 \%)$. The mean parity was $2.8 \pm 1.47$ ranging from $0-9$. The age at first intercourse ranged from 13- 33 years, mean being
17.88 \pm 3.07 years. The most common complaint was white discharge per vaginum (29.3\%). Next common complaints were lower abdominal pain, dyspareunia, and menstrual disturbances.

The Pap smear was normal or negative smear in $11.75 \%$, inflammation was reported in $77.5 \%$, ASCUS in $5.5 \%$, ASC-H in $0.25 \%$, AGUS in $0.5 \%$, LSIL in $2 \%$, HSIL in $1.5 \%$ and invasive cancer in $0.5 \%$. On colposcopic examination of 400 women $87.25 \%$ had Reid' index $\leq 2$ which was considered as normal and 51 women $(12.75 \%)$ had abnormal colposcopic finding with Reid's index $\geq 3$ who were subjected to biopsy of the suspicious area/ areas. The biopsy rate was $12.75 \%$ with CIN 2 and 3 reported in $2.75 \%$ and invasive cancer in $0.75 \%$. Pap smear in present study revealed a low prevalence of normal or negative smear $(11.75 \%)$. Majority of the smears had inflammation $(77.5 \%)$ which in Luthra's study were reported to be $70.3 \% .^{18}$ In present study ASCUS was seen in $5.5 \%$ of smears and LSIL in $2 \%$, the corresponding figures mentioned in Novak's is 3-5\% for ASCUS and $1.6 \%$ for LSIL. ${ }^{19}$ The other findings were ASCH in $0.25 \%$, AGUS in $0.5 \%$, HSIL in $1.5 \%$ and invasive cancer in $0.5 \%$. Our findings were like that reported by Osmanabad district RCT ${ }^{20}$ While Cronje et al reported a higher prevalence of LSIL and above smears, Luthra et al found lower prevalence (dysplasias $1.4 \%$ and carcinoma $0.15 \%$ ). In contrary Ghosh et al, reported abnormal pap smear in $3.7 \%$ cases only while Saleh et al in an Egyptian study, as 4\%. ${ }^{18,21-23}$

VILI is the visualization of cervix after application of Lugol's iodine. It is considered positive if SCJ or entire cervix or growth turned yellow (non-uptake areas). Recently the role of iodine application was reevaluated in studies done in India and Africa at 11 centers. ${ }^{24}$ IARC pilot study concluded that VILI can detect $92 \%$ of women with precancer or cancer, a sensitivity considerably higher than that of either VIA or cytology. Its ability to identify women without disease is like that of VIA (85\%), and lower than that of Pap smears. One study showed that VILI had a higher reproducibility than VIA. Among the visual test assessed, VILI seems to be a better promising approach, detecting $75 \%$ of all cases of HSIL compared to VIA and VIAM, which detected less than two-thirds of cases. The pooled sensitivity that has come of VILI (91.8\%; range $76-97.3 \%$ ) is no doubt greater compared to those of VIA $(76.9 \%)$ and VIAM $(64.2 \%)$. Surendra et al, reported sensitivity of VILI (75.4\%), compared to VIA (59.7\%), VIAM (64.9\%), HPV $(62 \%)$ and cytology $(57.4 \%)$ though the differences were not statistically significant. ${ }^{25}$ Further studies by Sankaranarayanan in 2003 concluded VILI to be well suited as an alternative to Paps in low resource setting. ${ }^{11}$ Outside India Sangwa-Lugoma in 2006 evaluated both visual screening test and found VILI to be more specific than VIA but less than Paps. They recommended further assessment. $^{26}$ Le $\mathrm{N}$ et al reported sensitivity and specificity for the VILI as equivalent to colposcopy with no statistically significant difference. They recommended 
VILI as one of primary screening test to increase screening frequency in rural China. ${ }^{27}$

Cervical cancer screenings based on visual technique that eliminates colposcopy ('see-and-treat' approach) may be good alternatives to cytology-based screening programs in developing countries. ${ }^{28,29}$ Visual techniques have shown to have high negative predictive value of more than $99 \%$ which reassures a woman negative by VILI that she need not further undergo any investigation. These women may however be advised to undergo a VILI after a minimum interval of 3 years (Juneja 2007). ${ }^{30}$ Only 10 $15 \%$ women who are test positive with visual techniques require further evaluation, thus making alternative tool acceptable as primary screening method. The present study used visual inspection with lugol's iodine to determine whether the specificity of the test can be further increased without any loss of sensitivity.

\section{CONCLUSION}

Considering the study results, we conclude that VILI has better sensitivity than the conventional cytology in detecting premalignant lesions of the cervix. The characteristics and accuracy of VILI encourages its use in not only rural settings but also well-established health care centers due to the high specificity shown in those settings. It is recommended that VILI should be routinely used as a screening test in all sexually active patients presenting to any of the health care facilities. Accordingly, they can be further investigated, referred, or treated at the same visit whichever is cost effective in that setting. A change in basic assumptions in global belief- to move from the accepted wisdom that cervical cytology is the standard for cervical cancer screening to new understanding that the visual screening methods also hold a significant potential is required. Visual screening tests are a new hope for bringing the cervical cancer under control. How successful it is, remains to be seen.

Funding: No funding sources

Conflict of interest: None declared

Ethical approval: The study was approved by the Institutional Ethics Committee

\section{REFERENCES}

1. Ferlay J, Soerjomataram I, Ervik M, Dikshit R, Eser S, Mathers C, et al. GLOBOCAN 2012: Estimated Cancer Incidence, Mortality and Prevalence Worldwide in 2012 v1.0. Available at http://publications.iarc.fr/Databases/Iarc-

Cancerbases/Globocan-2012-Estimated-CancerIncidence-Mortality-And-Prevalence-Worldwide-In2012-V1-0-2012

2. Forouzanfar MH, Foreman K, Lozano R. The Challenge Ahead: Progress and Setbacks in Breast and Cervical Cancer | Institute for Health Metrics and Evaluation. Available at http://www.healthdata.org/policy-report/challenge- ahead-progress-and-setbacks-breast-and-cervicalcancer

3. Hakama M, Chamberlain J, Day NE, Miller AB, Prorok PC. Evaluation of screening programmes for gynaecological cancer. $\mathrm{Br}$ J Cancer. 1985 Oct;52(4):669-73.

4. Consul S, Agrawal A, Sharma H, Bansal A, Gutch M, Jain N. Comparative study of effectiveness of Pap smear versus visual inspection with acetic acid and visual inspection with Lugol's iodine for mass screening of premalignant and malignant lesion of cervix. J Indian Soc Med Paediatr Oncol. 2012 Jul;33(3):161-5.

5. Sarian LO, Derchain SF, Naud P, Roteli-Martins C, Longatto-Filho A, Tatti S, et al. Evaluation of visual inspection with acetic acid (VIA), Lugol's iodine (VILI), cervical cytology and HPV testing as cervical screening tools in Latin America. This report refers to partial results from the LAMS (Latin AMerican Screening) study. J Med Screen. 2005;12(3):142-9.

6. Parkin DM, Bray F, Ferlay J, Pisani P. Global Cancer Statistics, 2002. CA Cancer J Clin. 2005 Mar 1;55(2):74-108.

7. Bhatla N, Mukhopadhyay A, Joshi S, Kumar A, Kriplani A, Pandey RM, et al. Visual inspection for cervical cancer screening; evaluation by doctor versus paramedical worker. Indian J Cancer. 2004 Jan 1;41(1):32.

8. Chou P, Chen V. Mass screening for cervical cancer in taiwan from 1974 to 1984. Cancer. 1989 Aug 15;64(4):962-8.

9. Lazcano-Ponce EC, Rascón-Pacheco RA, LozanoAscencio R, Velasco-Mondragón HE. Mortality from Cervical Carcinoma in Mexico. Acta Cytol. 1996;40(3):506-12.

10. Syrjänen K, Naud P, Derchain S, Roteli-Martins C, Longatto-Filho A, Tatti S, et al. Comparing PAP smear cytology, aided visual inspection, screening colposcopy, cervicography and HPV testing as optional screening tools in Latin America. Study design and baseline data of the LAMS study. Anticancer Res. 2005 Oct;25(5):3469-80.

11. Sankaranarayanan R, Wesley R, Thara S, Dhakad N, Chandralekha B, Sebastian $P$, et al. Test characteristics of visual inspection with $4 \%$ acetic acid (VIA) and Lugol's iodine (VILI) in cervical cancer screening in Kerala, India. Int J Cancer. 2003 Sep 1;106(3):404-8.

12. Denny L, Kuhn L, Pollack A, Wainwright H, Wright TC. Evaluation of alternative methods of cervical cancer screening for resource-poor settings. Cancer. 2000 Aug 15;89(4):826-33.

13. Denny L, Kuhn L, Pollack A, Wright TC. Direct visual inspection for cervical cancer screening. Cancer. 2002 Mar 15;94(6):1699-707.

14. Sankaranarayanan R, Nene BM, Dinshaw K, Rajkumar R, Shastri S, Wesley R, et al. Early detection of cervical cancer with visual inspection methods: a summary of completed and on-going 
studies in India. Salud Pública México. 2003 Jan;45:399-407.

15. Belinson JL, Pretorius RG, Zhang WH, Wu LY, Qiao YL, Elson P. Cervical cancer screening by simple visual inspection after acetic acid. Obstet Gynecol. 2001 Sep 1;98(3):441-4.

16. of Zimbabwe U, Project JC. Visual inspection with acetic acid for cervical-cancer screening: test qualities in a primary-care setting. The Lancet. 1999 Mar 13;353(9156):869-73.

17. Mitchell MF, Schottenfeld D, Tortolero-Luna G, Cantor SB, Richards-Kortum R. Colposcopy for the diagnosis of squamous intraepithelial lesions: a metaanalysis. Obstet Gynecol. 1998 Apr 1;91(4):626-31.

18. Luthra UK, Prabhakar AK, Seth P, Agarwal SS, Murthy NS, Bhatnagar P, et al. Natural history of precancerous and early cancerous lesions of the uterine cervix. Acta Cytol. 1987;31(3):226-34.

19. ADDIS I. Intraepithelial disease of the cervix, vagina, and vulva. Berek Novaks Gynecol. 2007;576-8.

20. Sankaranarayanan R, Nene BM, Dinshaw KA, Mahe C, Jayant K, Shastri SS, et al. A cluster randomized controlled trial of visual, cytology and human papillomavirus screening for cancer of the cervix in rural India. Int J Cancer. 2005 Sep 10;116(4):617-23.

21. Miller AB, Nazeer S, Fonn S, Brandup-Lukanow A, Rehman R, Cronje H, et al. Report on consensus conference on cervical cancer screening and management. Int J Cancer. 2000 May 1;86(3):440-7.

22. Ghosh P, Gandhi G, Kochhar PK, Zutshi V, Batra S. Visual inspection of cervix with Lugol's iodine for early detection of premalignant and malignant lesions of cervix. Indian J Med Res. 2012 Aug;136(2):265-71.

23. Saleh HS. Can visual inspection with acetic acid be used as an alternative to Pap smear in screening cervical cancer? Middle East Fertil Soc J. 2014 Sep 1;19(3):187-91.

24. Sankaranarayanan R, Basu P, Wesley RS, Mahe C, Keita N, Mbalawa CCG, et al. Accuracy of visual screening for cervical neoplasia: Results from an IARC multicentre study in India and Africa. Int $\mathbf{J}$ Cancer. 2004 Jul 20;110(6):907-13.

25. Shastri SS, Dinshaw K, Amin G, Goswami S, Patil $\mathrm{S}$, Chinoy R, et al. Concurrent evaluation of visual, cytological and HPV testing as screening methods for the early detection of cervical neoplasia in Mumbai, India. Bull World Health Organ. 2005 Mar;83(3):186-94.

26. Sangwa-Lugoma G, Mahmud S, Nasr SH, Liaras J, Kayembe PK, Tozin RR, et al. Visual inspection as a cervical cancer screening method in a primary health care setting in Africa. Int J Cancer. 2006 Sep 15;119(6):1389-95.

27. Li N, Ma CP, Sun LX, Zhang YZ, Shao SL, Xing $J X$, et al. Evaluation on the visual inspection with Lugol's iodine in cervical cancer screening program. Zhonghua Liu Xing Bing Xue Za Zhi Zhonghua Liuxingbingxue Zazhi. 2006 Jan;27(1):15-8.

28. Mandelblatt JS, Lawrence WF, Gaffikin L, Limpahayom KK, Lumbiganon $\mathrm{P}$, Warakamin $\mathrm{S}$, et al. Costs and benefits of different strategies to screen for cervical cancer in less-developed countries. JNCI J Natl Cancer Inst. 2002 Oct 2;94(19):1469-83.

29. Goldie SJ, Gaffikin L, Goldhaber-Fiebert JD, Gordillo-Tobar A, Levin C, Mahé C, et al. Costeffectiveness of cervical-cancer screening in five developing countries. N Engl J Med. 2005 Nov 17;353(20):2158-68.

30. Juneja A, Sehgal A, Sharma S, Pandey A. Cervical cancer screening in India: Strategies revisited. Indian J Med Sci. 2007 Jan;61(1):34-47.

Cite this article as: Bajaj M, Ahmad S, Trivedi SS Comparison of diagnostic value of visual inspection with Lugol's iodine to conventional Paps smear in detection of colposcopic biopsy proved CIN: a tertiary care experience. Int J Reprod Contracept Obstet Gynecol 2017;6:5477-82. 